\title{
The Rice Myths in Asia: The Comparative Literature Study
}

\author{
Sastri Sunarti ${ }^{1}$, Ninawati Syahrul ${ }^{2}$, Atisah $^{3}$, Erli Yetti ${ }^{4}$ \\ \{sastri.sunarti@gmail.com¹, ninawatisyahrul.bahasa@gmail.com ${ }^{2}$, atisah.shinutama@gmail.com ${ }^{3}$, \\ yettierli@gmail.com ${ }^{4}$ \} \\ The Agency for Language Development and Cultivation \\ Ministry of Education, Culture, Research, and Technology of Republic of Indonesia \\ Jalan Daksinapati Barat IV, Rawamangun, Jakarta Timur
}

\begin{abstract}
The main aim of the paper is to compare the rice plant myths from the Asian countries like Indonesia, Malaysia, The Philippines, Laos, Cambodia, Thailand, China, Japan, and India. Data was collected through literature study and then, ten stories of the rice myths will be analyzed uses the literary comparative study approach. The comparison includes the version, theme, and topoi of the story. The results of comparison are differences and similarities of the story based on topoi and theme. In addition, the rice myth is also closely related to the concept of the Mother Goddess; a concept that identifies the mother/woman as the earth or the source of life. Meanwhile, the most topoi which is found in the story are sacrifice and transformation that means respect and praise for the earth among the agrarian community culture.
\end{abstract}

Keywords: Myths of Rice plant; Asia; Comparative Literary Study; Topoi

\section{Introduction}

Several countries in Asia and India such as Indonesia, Malaysia, The Philippines, Laos, Cambodia, Thailand, China, Japan, and India have the culture of rice cultivation. Rice not only for consumes but also integrated with their living traditions. That's way so many folklores, myths, legends, oral history, rite, ceremony relate to the rice in Asia and India. They treat rice as an important elements and inseparable culture among their life. For instance, the Javanese in Indonesia consider the rice plant as one of the sacred plants in their culture. The rice uses in rite passage of birth, marriage, and the death ceremony like a tumpeng (the rice like a miniature of mountain and placing on the big plate with some of boiled eggs, fried chicken, tempe bacem, tofu, vegetables. The rice is colored yellow using turmeric.

Similar in the Vietnamese, especially among the Tháy ethnic groups, describes how people using the rice in their life cycle. The rice uses in their religions, the rite passage, and in the daily life. As a glutenious eater, they have several ways how to cooked, to cultivated rice, and to respect the rice plant appropriately. Like the kin kau mo is a newly harvest festival as the most popular feast among the Tháy groups [1]. In additions in Laotians and Thailand have some myths which is telling the rice existence and how they learn to cultivate of the rice plant. According to the myth of Pu Sangkasa and Ya Sangkasi, for instance, were thrown up in the 
sky and fell onto the ground and then they grew into various plants and crops. Pu and Ya after landed in the ground, showed humans how to grow rice and forage for food [2]. Meanwhile, most of the rice spirits in Asia and India's myth are females and often a mother figure. The spirit has several names and depending on where the story is generated. In Indonesia, for instance, the goddess of the rice myth is known by various names such as the Sri Goddess (Dewi Sri), Sang Hyang Pohaci, Si Beru Dayang and others. Etymologically, the word Sri comes from Sanskrit and means fertility, wealth, luck, health, and beauty [3]. In China they call as, the Guan Yin, Kuan Yim, Kwam Im (most popular among the Chinese community in Indonesia), or Kuan Yin, is a short form for Kuan-shi Yin, meaning "Observing the Sounds (or Cries) of the (human) World”, Hou Tu, and Lử Tung Ping [4].

The rice myths is classified as the origin of the story of the main plant as the research conducted by researcher from the Literary Studies Department of Language Development and Cultivation Agency, Ministry of Education and Culture of Indonesia. The research managed to collect as many as 19 stories of the origins of the rice plants, such as 1) Asal Mula Padi dari Cerita Rakyat Flores (The Origin of Rice in The Flores Folktale; 2) Asal Mula Tanaman Padi dari Cerita Rakyat Madura (The Origin of Rice Plants of The Folktale in Madura; 3) Asal Mula Padi dari Cerita Rakyat Jawa Barat (The Origin of Rice in The Folktale of The West Java; 4) Asal Mula Padi dari Cerita Rakyat Bali (The Origin of Rice in The Folktale of Bali), 5). Dari Mana Asal Padi dari Cerita Rakyat Sulawesi (The Origin of The Rice Plant in The Celebes Folktale); 6) Cerita Tentang Padi dari Cerita Rakyat Pulau Kei (The Story about Rice in The Kei Island Folktale); 7) Asal Mula Padi dari Cerita Rakyat Kalimantan (The Origin of Rice in The Borneo Folktale); 8) Si Beru Dayang, (The Karo Folktale of North Sumatra) and 9). Asal Mula Padi dari Jawa Barat (The Origin of Rice in The West Javanese Folktale). Grubben and Partohardjono, describe that the rice plants as a type of grass, raised $50-130 \mathrm{~cm}$ [5]. The rice plants physically have fibrous roots, erect trunks and stems with nodes. And also have panicle-shaped flowers, while the fruit is whitish yellow or brown depending on the type of variety [6]. These plant spreads over two continents like the Asian continent and the western part of Africa. Historical evidence shows that rice cultivation in Zhejiang China began in 3,000 BC. Fossils of grain were found in Hastinapur Uttar Pradesh India around 100--800 BC. In addition to China and India. Some areas of origin of rice plants are Northern Bangladesh, Burma, Thailand, Laos, and Vietnam [7].

In additions, according to Oppenheimer, the rice plants have been planted in the mainland of Southeast Asia in 6000-7000 BC, that is on the Thai peninsula which is much earlier than the discovery in China [8]. Koentjaraningrat [9], argues that the initial center of rice cultivation in the Southeast Asia, was in the area of big rivers such as the Mekong, Salwin, Irawadi and others. Then it spread further to the Southeast Asian Archipelago, such as Indonesia, the Philippines and even to the Gangga's river area in India. Archaeological research at the site 'Sireh Cave', Sarawak Malaysia conducted by Ipoi Datan, succeeded in finding the remains of rice husks that were still attached to the pottery. Through the dating method, it can be seen that the age of the rice bran comes from 2000 BC or 4000 years ago. Thus, it can be concluded that rice has been cultivated since 4000 years ago in Sireh Cave [10]

Crystal in Meneses [11] explains that rice has influenced many aspects of the Southeast Asian village traditions, including religion and social order. In many parts of the Southeast Asia, the caste system has organized society hierarchically. Those who own the land to grow rice are the most powerful. A lot of time and details were dedicated in creating the elaborate storage facilities and containers for rice. As noted by Dr. Crystal, "a special ceremony is performed when rice is brought from the fields and stored in the barn." All areas where rice is found, such as fields, granaries, and refineries, are considered as sacred spaces. 


\section{Research Methods}

This research uses descriptive qualitative method. The data is obtained from literature research sourced from the internet and books. The selection of story texts is based on the mythical rice story in the Asian region. The discussion of the story of the origins of rice from the Asian countries will be (1) the version of the story; (2) themes, (3) similarities and differences in topoi (a major part of the old rhetorical tradition was the use of commonplaces); and (4) the concept of the goddess which contained in the story. With an intensive reading technique (close reading), the text will be analyzed by using a comparative study, such as the intrinsic elements in the entire text. There are two schools of thought in comparative literature, the first is the French school and the second is the American school.

The French school emphasizes comparative literary work as a comparison between two or more literatures. The American school emphasizes comparative literary studies with other fields such as psychology, sociology, art, music, philosophy, politics, and others. Wellek and Warren explain in more detail that comparative literature breaks through geographical and environmental boundaries. Comparative literature also derived from the oral literature study of a community group, especially one that looks at the themes and directions of changes in story development as an academic study and has literary value [12]. This is in line with the opinion of Damono [13] that one of the activities that has been carried out by comparative literature reserchers is to compare similar fairy tales from various countries, otherwise to reveal which ones are genuine and their influence on others, but rather to find out the links between differences and similarities that exist in the character of a society. Further, Damono explains that the notion of fairy tales here includes all kinds of stories classified as Khayangan 'heaven', mythology, and fables in Western terminology.

Remak [14] explains that the comparative literature compares historical events, literary relations, similarities and differences, themes, genres, styles, tools of cultural evolution, and so on. Remak further limits the object of comparative literature. According to Remak, the objects of the comparative literature study is not only the national literary works but also the world literary works. In addition, it can be understood that the basis of comparison is the similarity and relationship of the text. So, the essence of the comparative literary studies is to look for differences, in addition to the similarities and relationships of the texts, the most important thing from the comparative literary studies is how a researcher is able to find and compare the distinctiveness of the literature being compared.

The comparative Literature is one of the gates to enter the aspect of cultural studies. As explained earlier, one of the studies in the comparative literature study is the theme aspect. The reason is very simple, because the theme is one of the important elements that determine the existence and degree of the works. In fact, it is the theme that can make a work great. Furthermore, it must also be acknowledged that the theme is always the central element in the work. It can be about themes, plots and figures (intrinsic) and characterization and stylistics (extrinsic). In additions comparing themes, it is also possible to compare characters, and topoi in the story, such as the topoi of the origin of rice which found in the rice myths in the Asia and India will be discussed next in this paper.

\section{Result and Discussion}

\subsection{The Versions of the Rice Myths}


The rice myths which are discussed in this paper come from several countries in Asia such as Indonesia, Malaysia, the Philippines, Laos, Cambodia, Thailand, Vietnam, China, Japan and India as mentions before. In Indonesia, the Goddess Sri is connected with the origins of the rice plant. The Goddess Sri is associated with the myth of the origin of the rice plant. There are a lot of versions of the the Goddess Sri stories in Indonesia. Some of them is known as Dewi Sri, Sang Hyang Pohaci, Si Beru Dayang, etc. One of the versions of the story mentions that the figure of Sri incarnates into a snake and the character of Sadhana becomes a bird. The siblings are transformed into the generous Gods and dedicated their life for the prosperity of the Javanese people. Sri has the task to ensure the fertility of the land, the art of offerings in harvesting and the rice planting itself. Meanwhile, Sadhana has the task to ensure prosperity. On the other hand, the story of Sri and Sadhana is actually influenced by details of rice agriculture and the sustainability of the product. Thus, the story of Sri and Sadhana is actually highlighted with the details of Dewi Sri's way regarding the agriculture and production [15].

Base on beliefs, traditions, and mythology in Indonesia, The Goddess Sri at least appears in the communities of Javanese, Bugis, Batak, Balinese, Borneo, North Sumatran, and Ende. In the manuscript of the I La Galigo for example, a mythology from the Bugis tribe of South Sulawesi, Indonesia, explained that the rice plant grew from We Oddangriu's grave. We Oddangriu' is the son of Batara Guru and We Sessungriu' who died three days after his birth. After he die, he re-incarnation to be Sangiang Serri 'or the Goddess of Rice [16]. And then, the Bugis people cult Sangiang Serri' as a hope for abundant harvests [17]. While in the legend on the island of Borneo, mentioned that the rice plant came from Luing Ayang who was killed by Soong Putes Tamun Jues by a Mandau weapon. Before his death, Luing Ayang said: "I am Luing of the heavens. But with you, I am the rice plant!" [18]. Another version of the story of the origin of rice in Indonesia comes from the Central of Borneo, namely the story of the Ngaju Dayak tribe. According to them, rice comes from Pantis Kambang Kabanteran Bulan Lelak Lumpung Matanandau 'falls from the moon of the seventh sky' and grows on the hill of Kagantung Gandang (seventh heaven). "Putir Selung Tamanang" and "Raja Angking Tingang", the two closest assistants of "Ranying Hatalla (highest place)" were assigned to guard and protect the rice. The spirit in the rice is the spirit of the two of them.

The diversity of the rice myths in Asia shows us how the paddy's culture is inseparable with the people in these areas. From the rice myths we can find the similarities of theme, topoi, and character of the stories. The similarity of theme of the rice myths indicates that in the past there were common cultural belonging in this region. In India, for example, Hinduism has a strong influence on the origin of the rice plants story. Goddess Lakshmi, wife of Lord Vishnu, is a central figure in Indian rice mythology. In addition, the name of The Goddess Sri is also closely related to Buddhist teachings. This is traced, among others, to the use of another name, Sridevi, which is the personification of Dharmapala, the protective Goddess in the teachings of the Dalai Lama in the old sect of Buddhism.

However, in the development of tradition and mythology in Indonesia, the legend of The Goddess Sri is no longer fully rooted in the belief of Hinduism and Buddhism. This also explains a number of findings of differences in the form of The Goddess Sri in statues that are thought to have been made in the Hindu, Hindu Buddhist, and later eras. In fact, the depiction of The Goddess Sri in Indonesia and in India, the country which is believed to be the origin of Hinduism and where the majority of the population is Hindu, she is also called by a different name. The different symbolism discussion of The Goddess Sri in Hinduism, Hindu Buddhism, and traditions in the archipelago is related to the Sri Goddess, according to the Indonesian 
iconographic treasures who were found in the statue of The Goddess Sri which is ichnographically different in its depiction from The Goddess Sri in India [19].

In China, the rice comes from the body of a woman named Guan Yin, Kwam Im or, other version is Lo Yien. Lo Yien was born from the tears of Yang (Yang Tie) which became an egg and was incubated by a dragon. Lo Yien was adopted by Yang and Yin. When she grew up, Lo Yien was killed by Yin because her husband Yang lusted after her. From her body emerged rice plants that can be eaten by humans. The story is similar to the sacrifice of Luing Mayang or Ni Luing whose body became rice in The Balinese story. While in Japan, the story of the origin of the rice plants comes from the body of 'Inari,' The Goddess who committed suicide because she was about to be married to her own brother, Susanoo (God of the Sea). In another version, it is told that the rice plant came from the body of the Goddess Ohogetsu, Susanoo's sister-in-law (God of the Sea), named Tsukiyomi (God of the Moon). Goddess Ohogetsu was killed by Susanoo for serving food to him by chewing and then spitting it out so that it turned into delicious food, which disgusted Susanoo [20].

Meanwhile in Southeast Asia, the story of the origin of the rice spread in Indochina and the islands of Southeast Asia. In Indochina, the rice emerged from the body of "Poh Lowin" who was slaughtered by Poh Ane because she was going to be married by her adoptive father. In other hand, the story of the origin of the rice plant is included to the classification of the myth genre. The Myths are usually related to stories about creators, gods, cosmogony and cosmology. The important thing in the oral stories study is to find the main intrinsic elements. As mention by Danandjaya as the main element or theme [21], or the narrative elements. The one of the narrative elements which always found in the rice myth is the figure of the mother goddess. She is a symbol of life and fertility in ancient beliefs [22]. The God or Goddess are symbolizing of fertility which is often found in agrarian communities, especially among the farmers of paddy.

In addition, in the rice myth, also can be find some topoi (a major part of the old rhetorical tradition was the use of common places). The similarity of the topoi can occur due to monogenesis or polygenesis. Monogenesis means that there are similarities due to independent or parallel inventions from various ethnic groups. Polygenesis is the discovery that follows the process of diffusion or spread. In the process of spreading the topoi are changed and adapted with various variations that are adapted to the cultural environment and geographical environment. With that process, various versions of the story were created. Through the variety or versions of this story, it can be traced and a common thread that shows unity of various ethnic groups, such as the story of the origin of rice plants from several countries in Asia which will be discussed below.

\subsection{Version, Topoi, and Themes in the Rice Myths}

There are 10 versions of the rice myths in Asia with the following titles: The Goddess Sri or Sang Hyang Pohaci (Indonesia); Semangat Padi/Rice Spirit (Malaysia); Sappia, Bulul, Ampu at Paray, Ibabasok, and Pilay (The Philippines), Nang Khosop (Laos); The version of the rice story can be seen from the various titles and text which found in several countries in Southeast Asia, Far East Asia, and South Asia as can be seen in the table below. While topoi are characteristics in oral stories that can be recognized and appear repeatedly. As for what is meant by topoi, it is part of the information or narrative whose content is fixed on a certain topic. The topoi are not bound in form such as numbers or runs, which are descriptions or expressions of relatively constant form. However, topoi can contain numbers as well. The topoi can be seen as a "recipe" or series of stages that a dalang (puppeteer) will rely on when 
delivering a portion of a repertoire or a scene that occurs frequently and is intended to produce adaptations of the show for harmony [23]. Some of the Topoi that appear in the origin rice plants stories from Asia are topoi of incarnation (re-incarnation), sacrificing, battle, the sky and the earth. As shown in the table below.

Table 1. Version, Theme and Topoi of the Rice Myths in Asia

\begin{tabular}{|c|c|c|c|c|c|}
\hline Country & Version & $\begin{array}{c}\text { The Main } \\
\text { Theme }\end{array}$ & Topos (1) & Topos (2) & Topos (3) \\
\hline Cambodia & $\begin{array}{l}\text { The Pho Ino } \\
\text { Nagar Goddess }\end{array}$ & $\begin{array}{l}\text { The battle of } \\
\text { the Gods in } \\
\text { Heaven }\end{array}$ & Sacrificing & $\begin{array}{l}\text { Re-incarnation from } \\
\text { Goddess to be a rice } \\
\text { plant }\end{array}$ & $\begin{array}{l}\text { The Sky } \\
\text { and the } \\
\text { earth }\end{array}$ \\
\hline China & $\begin{array}{l}\text { The Guan Yin, } \\
\text { Kwam In, Hou } \\
\text { Tu, Lo Yien, and } \\
\text { Lü Tung-pin } \\
\text { Goddessess }\end{array}$ & $\begin{array}{l}\text { The battle of } \\
\text { the Gods in } \\
\text { Heaven }\end{array}$ & Sacrificing & $\begin{array}{l}\text { Re-incarnation from } \\
\text { Goddess to be a rice } \\
\text { plant, animals bring } \\
\text { the rice crops to } \\
\text { human. }\end{array}$ & $\begin{array}{l}\text { The Sky } \\
\text { and the } \\
\text { earth }\end{array}$ \\
\hline Laos & $\begin{array}{l}\text { The Nang Khosop } \\
\text { Goddess }\end{array}$ & $\begin{array}{l}\text { The battle of } \\
\text { the Gods in } \\
\text { Heaven }\end{array}$ & Sacrificing & $\begin{array}{l}\text { Re-incarnation from } \\
\text { Goddess to be a rice } \\
\text { plant, }\end{array}$ & $\begin{array}{l}\text { The Sky } \\
\text { and the } \\
\text { earth }\end{array}$ \\
\hline Indonesia & $\begin{array}{l}\text { The Sang Hyang } \\
\text { Pohaci, Dewi Sri, } \\
\text { Sanghiyang Asri, } \\
\text { Beru Dayang } \\
\text { Goddess, etc. }\end{array}$ & $\begin{array}{l}\text { The battle of } \\
\text { the Gods in } \\
\text { Heaven } \\
\text { because of the } \\
\text { beauty of The } \\
\text { Goddess Sri }\end{array}$ & Sacrificing & $\begin{array}{l}\text { Re-incarnation from } \\
\text { Goddess to be a rice } \\
\text { plant. } \\
\text { From human to be a } \\
\text { plant; from A red } \\
\text { bird to be red rice, } \\
\text { the black bird to be } \\
\text { black rice, and A } \\
\text { white bird to be } \\
\text { white rice }\end{array}$ & $\begin{array}{l}\text { The Sky, } \\
\text { field, and } \\
\text { the jungle }\end{array}$ \\
\hline India & $\begin{array}{l}\text { The Lakhsmi } \\
\text { Goddess }\end{array}$ & $\begin{array}{l}\text { The cults for } \\
\text { The Goddess } \\
\text { Lakhsmi }\end{array}$ & Sacrificing & $\begin{array}{l}\text { Re-incarnation from } \\
\text { Goddess to be a rice } \\
\text { plant }\end{array}$ & $\begin{array}{ll}\text { The } & \text { Sky } \\
\text { and } & \text { the } \\
\text { earth } & \end{array}$ \\
\hline Japan & $\begin{array}{l}\text { The Inari, } \\
\text { Ohogetsu } \\
\text { Goddesess }\end{array}$ & $\begin{array}{l}\text { The murder of } \\
\text { the } \\
\text { Ohodetsu } \\
\text { Goddes }\end{array}$ & Sacrificing & Re-incarnation & $\begin{array}{l}\text { Sky and } \\
\text { the earth }\end{array}$ \\
\hline Malaysia & The Spirit of Rice & $\begin{array}{l}\text { The killing of } \\
\text { a boy/girl }\end{array}$ & Sacrificing & $\begin{array}{l}\text { Re-incarnation from } \\
\text { being a human to be } \\
\text { a rice plant }\end{array}$ & The earth \\
\hline $\begin{array}{l}\text { the } \\
\text { Philippines }\end{array}$ & $\begin{array}{l}\text { The Sappia } \\
\text { Goddess and the } \\
\text { bold man }\end{array}$ & $\begin{array}{l}\text { Drough and } \\
\text { mercy of the } \\
\text { Goddess }\end{array}$ & Sacrificing & $\begin{array}{l}\text { Re-incarnation from } \\
\text { a human to be a rice } \\
\text { plant }\end{array}$ & $\begin{array}{l}\text { The Sky } \\
\text { and the } \\
\text { earth }\end{array}$ \\
\hline Thailand & $\begin{array}{l}\text { The Mae Ku'sok } \\
\text { Goddess }\end{array}$ & $\begin{array}{l}\text { Drough and } \\
\text { mercy of the } \\
\text { Goddess }\end{array}$ & Sacrificing & $\begin{array}{l}\text { Re-incarnation from } \\
\text { Goddess to be a rice } \\
\text { plant }\end{array}$ & $\begin{array}{l}\text { The Sky } \\
\text { and the } \\
\text { earth }\end{array}$ \\
\hline Vietnam & $\begin{array}{l}\text { The Thien } \mathrm{Ya} \mathrm{Na} \\
\text { Goddess }\end{array}$ & $\begin{array}{l}\text { The merciful } \\
\text { Goddess }\end{array}$ & Sacrificing & $\begin{array}{l}\text { Re-incarnation from } \\
\text { Goddess to be a rice } \\
\text { plant }\end{array}$ & $\begin{array}{l}\text { The Sky } \\
\text { and the } \\
\text { earth }\end{array}$ \\
\hline
\end{tabular}

\subsection{Types of Topoi in the Rice Myths}

\section{a) Topos of Sacrifice}


Sacrificing is one topos that is almost found in all the rice myths from Asia. In the mythical story of rice from Indonesia, the sacrifice was made by Sang Hyang Pohaci when she was killed by the gods for not agreeing to her marriage to Batara Guru. Sacrifice is also found in the rice myth from the Philippines when the Goddess Sappia sacrificed her breast milk and even her blood for the grass to grow rice grain and eliminate drought and hunger on earth. Similar with the rice myth of the Philippines, in China, the Guan Yin Goddess one day went to the rice fields secretly and squeezed her breasts until her milk flowed into the ears of the rice plants. After that, she pressed harder and a mixture of blood and milk flowed into the plants. This story remaining us why the rice have white and red colours today. Meanwhile, the sacrifices made by The Mae Ku'Sok in the rice myth from Siam (Thailand) is willing to return to the land of Siam even though she was harassed by an old widow. In other version of the rice myth from China, the character Lo Yien was killed by the jealous goddess Yin because her husband had fallen in love with Lo Yien. So did either with the Goddess Ohogetsu from Japan. She was killed by Susanoo for serving food to him by chewing and then spitting it out so that it turned into the rice.

\section{b) Topos of Incarnation}

In general, this story about the origin of the rice myth explains various events of incarnation (transformation) that occurred before the emergence of the rice plant. The events explain to the reader that there is a belief related to the religious system adopted by the people who support the story of the origin of this plant and the acknowledgment of the existence of the Creator of nature and the contents as well. This transformation process is often described as taking place thanks to the intervention of gods and rulers of the sky (khayangan). The form can be in the form of a group of gods, mystic elderly, ascetics (India, Laos, Cambodia), men (Japan, Philippines), old widow women (Thailand), and conveyed through dreams (inspiration in sleep) and so on.

Topos incarnation can take the form of the incarnation of a god into a human, or a god becoming a plant, or a human becoming a plant. The most common are topos of the Goddess who transforms into a plant or a boy who turns into the rice (Malaysia), a dragon that turns into a Goddess and then transforms into the rice (China), other creatures or objects. For example, in the story of the origin of the rice plant from Indonesia, the character comes from an egg and then transforms into a beautiful princess, namely Nyi Pohaci Sanghiang Sri. When she grew up, Nyi Pohaci had to be killed so she wouldn't marry Batara Guru who was her own adoptive father. After being killed, Nyi Pohaci reincarnated into various plants such as the rice, the coconut, the palm trees, the pulut rice and the grass. Several Sundanese printed works also contain this story about Nyi Pohaci Sanghiang Sri. The story about Nyi Pohaci can be found in works entitled Wawacan Pohaci, Cariyos Sawargaloka, Wawacan Sanghiyang Sri, Wawacan Puhaci Dangdayang, Wawacan Dewi Sri, and Carita Sulanjana. These stories are already in the written form, both in the script and the stencil prints. However, in some areas of West Java, the stories about Pohaci Sanghiyang Sri are still conveyed orally [24].

\section{c) Topos of the Upper World and the Lower World (the Sky and the Earth)}

It can be said that all the rice myths from Asia have two kinds of worlds such as the upper world (the sky; khayangan) and the lower world (the earth). The upper world represents of the sky, khayangan (heaven), the place for the God and Goddess leave. Meanwhile, the lower world represents of the earth, the place where human leave is. The sky also can be 
interpretation as a belief to the God. It means that the rice myths related to the religious system in Asia. As we can find in the ancestral culture of the Dawanese community, East Nusa Tenggara, of Indonesia who were believed in the Uis Neno (the God of the sky) and the Uis Pah (the God of the earth), [25].

Meanwhile, belief in the spirit in the rice myths from Malaysia shows that this story was developed before the Islamic era in the Malay world. In that era, the Malay people believed in the spirit whom was fallen down to the earth from the sky. Likewise, the rice myth from Thailand explains that the character Mae Ku'sok is a fertility goddess in Buddhis which is believed to derived from the sky. The character of Lo Yien, from the rice myth of China, was originally a dragon egg from the sky which was adopted by Yin and Yang and then derived to the earth and become the rice plant after being killed by Yin. Similarly with other stories, The Goddess Lakshmi as the wife of Lord Vishnu in India is the Goddess of prosperity and fertility who resides in the sky, the place for the gods are sitting. In Indonesia, the topos of the "upper world" is described in the following quote:

"All the gods in the sky then look for ways to the Batara Guru's intentions. There is no other way but to just kill the Sangiang Sri. So the gods then gave poison to Sangiang Sri and because of the poison, the Sangiang Sri then died, and was buried in the earth".

Based on quote we can see that the Batara Guru (the God) is sitting on the sky (khayangan), including the Sangiang Sri. But after she killed by the other Gods, her grave site is in the earth. It means she is not immortal anymore and becoming mortal like the human. And as the mortal she is belong to the earth otherwise to the sky. In another the rice myth like from India, Japan, and China, the upper and the lower world topoi also found. In other hand, we can say that the existence of the "upper world" or khayangan is a representation of the belief system among the Asian community. They believe to God existence as the great creator beside human being.

\subsection{The Concept of The Goddess Mother in The Rice Myths}

The concept of Ibu Dewi (The Goddess Mother) is a concept that identifies the mother/woman as the earth or source of life. Associating rice with the Mother Earth is a high appreciation for the rice plant as a source of life. This belief shows how important the plant is in the culture of its supporting community, especially in agrarian societies such as in Southeast Asia, East Asia, and South Asia as mention above. The narrative of the origin of rice plant in general is also related to the concept of fertility that grows and develops in an agrarian society. The symbols of the Goddess in the story are a representation of the fertility and wealthy. And they have several names in the rice myth. In Malaysia for instance, they are called as Anak Sembilan Bulan (The Nine-Month Child), Anak Maharaja Cahaya (Son of the Maha Raj of Light), Si Dang Sari, Si Dang Rupa Seri, Si Dang Seri Tongkat, Si Dang Tatap, Si Dang Yas, Seri Gading, and Gejala Dading. In the Philippines, it is known as Sappia and Bulul, in Laos the rice goddess is Nang Khosop, in Thailand, Mae Ku' Sok, in Cambodia the rice goddess as Po Ino Nogar, in China as Lo Yien, in Indo China as Poh Lowin, in Japan as The Inari Goddess, and in India as the Lakshmi Goddess.

In Indonesia, especially in the Javanese and Balinese community, the symbol of fertility is represented by a goddess called The Sri Goddess (in the Babad Ila-Ila), Sri Sadana (in the Kentrung show, Banyuwangi). In the West Java, it is called Nyi Pohaci Sangiang Sri or Pohaci 
Sanghiyang Asri which is contained in various published and oral stories. In Borneo, the symbol of fertility is represented by a character called Luing Indung Bunga Princess. She is considered the incarnation of the Goddess of Fertility in Kaharingan religious beliefs. The Karo Batak people believe that the symbol of fertility is Si Beru Dayang; the figure of a young boy. Likewise, stories of the origin of plants from Sulawesi and Aceh suggest that the fertility comes from human bodies that are sacrificed or surrender themselves as victims voluntarily in order to create fertility in their homeland.

The concept of fertility is usually associated with the Mother Goddess belief, which is an old cultural element which is believed to have been embraced by various cultures in the world since the Upper Paleolithic period, especially in Eastern and Central Europe. This concept was initially embraced by the people of Gravettian culture community, James and Santiko [26]. The concept of worshiping the Mother Goddess is also embraced by other agrarian communities in the world which we find in Indonesia as well as in other agrarian countries such as Thailand, Myanmar, and India, especially those who still carry out the tradition of growing rice in the fields.

The concept of the Mother Goddess identifies the mother as equal to the land. This concept in Javanese society culture can be identified as The Sri Goddess, or also known as The Rice Goddess or Nyi Pohaci Sangiang Sri in the Sundanese society according to Santiko [27]. The concept of the Mother Goddess is also related to the plants which are needed by humans. The process goes through rebirth or re-incarnation which later will be encountered a lot in topoi (scenes, events, common place) and are found repeatedly in a narrative such as stories of the origin of plants in Asia. James [28] stated that The Sri Goddess, also known as Tisnawati is a symbol of plant seeds. Seeds will grow and break after being planted first in the soil and giving birth to or grow a new plant.

The Sri as the Rice Goddess is also a symbol of happiness as well as fertility as written in the Serat Babad ila-ila in the traditional Javanese manuscripts. The Javanese society manifests the myths of Sri Goddess with village "cleansing" rituals which are usually carried out after harvest by performing the wayang purwa play Sri Sadana or Sri Mulih as a symbol of hope and fertility. In its development, the village "cleaning" ceremony is interpreted in various ways by the Javanese today, so that it is not only carried out after the rice harvest but also for other purposes. Thus, clean villages in Java are also known as metri dusun (village), ruwah rosul, alms of the earth, and so on [29] .

In India, expressions of gratitude for the Lakhsmi Goddess is manifested in the Sri Yantra's beliefs. In China, it is expressed in the rice harvest feast celebration. While in Japan, it is expressed in the New Year celebration. And in Indonesia, the success of the harvest is manifested through dances and rhymes called Dero and Sagi dance in the Ngada community, Bajawa, and So'a [30]. In the West Java, the expression of gratitude for the abundant harvest is manifested in the Seren Taun ceremony. It can also be expressed by the reading of Sundanese rhymes such as the Lutung Kasarung story which is considered sacred because it contains teachings from the Lutung Kasarung character who is the incarnation of the Guru Minda; son of The Sunan Ambu; the ruler of Heaven who taught orang buana panca tengah-bumi (the people of the Five Middle Ages - the Earth) to cultivate the rice. In The Tanah Karo, this fertility ceremony is performed in an umpasa (reciprocal rhyme). The same is done in the basisomba (reciprocal rhyme) tradition in Minangkabau or through the Randai and the Bahikayaik (storytelling) performances [31]. 


\section{Conclusion}

Based on the rice myths in Asia that become data in this research, it can be concluded that the rice is an important and sacred plant for the Asian. Through the comparison of versions, themes, topoi and characters are find out the theme of the sacrificing of a woman (The Mother Goddess) from the Goddess becoming the rice plant. And then we can conclusion that the rice myth has several topoi such as the upper world (the sky) and the lower world (the earth) topoi. These topoi are associated with the religions and beliefs among the Asian people. In additions, topos of the incarnation from the Goddess to the rice plant are associated with the sacrificing, cults, and invoke of the Goddesses. The intrinsic elements contained in the rice myths from Asian countries indicate that they have a cultural familiarity for a nation who has glorifies the rice plant as the main source a food since the ancient times.

The narratives of the original rice plants can be useful information source for people in Asia to understand each other culture and community. It can help them to overcome the political rigidity through the similarities of the rice myths. The stories can be transformed into animation and digitalization products. The products of animation are easier to share around the world and can bring the Asia brotherhood closer to each other. It can also be soft diplomacy approach for the politicians in Asia.

\section{References}

[1] T. T. G. L. and H. L. Nguyên Xuân Hiên, "Rice in the Life in the Vietnamese Thay and Theire Folk Literature," Anthropos, vol. 99, no. 1, pp. 111-141, 2004, [Online]. Available: http://www.jstor.org/stable/40466309. .

[2] P. Nosuwan, Areerat and Honsuwan, "The Identity and the Hero in Lao Myths.," Mekong Soc., vol. 7, no. 22, pp. 109-128, 2011, [Online]. Available: https://so03.tcithaijo.org/index.php/mekongjournal/article/view/6206.

[3] M. Webster, Merriam Webster's Collegiate Dictionary. United States of America: Merriam Webster Incorporated, 2004.

[4] Anonim, "China: on the Origin of Rice-Myths, History and Folklore." 2014, [Online]. Available: https://www.earthstoriez.com/myths-history-folklore-rice-china.

[5] Grubben and Partohardjono, Plant Resources of South-East Asia. Bogor: Prosea, 1996.

[6] Purnomo, Tanaman Kultural dalam Perspektif Adat Jawa: Kajian Aspek Filosofi, Konservasi dan Pemanfaatan Tanaman dalam Kultur dan Tradisi Jawa. Malang: Universitas Brawijaya Press, 2013.

[7] Syekhfani, "Padi (Oryza Sativa)," 2013.

[8] S. Oppenheimer, Eden in The East, Surga di Timur. Jakarta: PT Ufuk Publishing House, 2010.

[9] Koentjaraningrat, Beberapa Pokok Antropologi Sosial. Jakarta: PT. Dian Rakjat, 1974.

[10] K. Yulianto, Awal Pertanian Padi di Indonesia. Jakarta: Diterbitkan atas kerjasama Fakultas Sastra Universitas Indonesia dan PT. Intermasa, 1995.

[11] R. Meneses, The Art of Rice:Symbol and Meaning in South East Asian Village Tradition. UCLA. Asia Pacific Centre, 2004.

[12] S. Mohd. Saman, Sastera Bandingan, Konsep, Teori dan Amalan. Penerbit Fajar Bakti SDN. BHD, 1986.

[13] S. D. Damono, Pegangan Penelitian Sastra Bandingan. Jakarta: Pusat Bahasa Departemen Pendidikan Nasional, 2005. 
[14] H. H. Remak, Contemporary Literature, Methods and Perspectives. Illnois: Carbondale \& Edwardsville, 1971.

[15] Sumintarsih, "Dewi Sri dalam Tradisi Jawa," Jantra, vol. II, no. 3, pp. 136-144, 2007.

[16] H. Kern, I La Galigo Cerita Bugis Kuno. Yogyakarta: Gadjah Mada University (UGM) Press, 1993.

[17] I. Surur, F., Sitorus, S.R.P., dan Agusta, "Pertimbangan Aspek Sosial Budaya dan Kearifan Lokal dalam Pengembangan Kawasan Danau Tempe Provinsi Sulawesi Selatan," Tata Loka, vol. 16, no. 3, pp. 168-180, 2014.

[18] A. . El Marzdedeq, Parasit Akidah, Perkembangan Agama-Agama Kultur dan Pengaruhnya terhadap Islam di Indonesia. Bandung: Sygma Creative Media Corp, 2014.

[19] T. S. N. Nastiti, "Dewi Sri dalam Kepercayaan Masyarakat Indonesia," Tumotowa, vol. 3, no. 1, 2020.

[20] Anton WP, Izanagi x Izanami, Kisah Dewa-Dewi Jepang dari Negeri Matahari. Solo: Penerbit BukuKatta, 2013.

[21] J. Danandjaja, Folklor Indonesia: Ilmu Gosip, Dongeng, dan lain-lain. Jakarta: PT Grafiti Pers., 1984.

[22] M. . Utsman, "Dewi Sri dan Masyarakat Agraris Jawa," 2012.

[23] A. Sweeney, A Full Hearing: Orality And Literacy In The Malay World. Berkeley: University of California Press, 1987.

[24] M. Holil, Sumber Lisan dan Teks Upacara Seren Taun di Cigugur Kabupaten Kuningan. Dalam Teks, Naskah, Dan Kelisanan Nusantara. Achadiat Ikram. Jakarta: Yayasan Pernaskahan Nusantara, 2011.

[25] Y. Y. Taum, "Tradisi Fua Pah: Ritus dan Mitos Agraris Masyarakat Dawan di Timor." 2004, [Online]. Available: https://www.academia.edu/3231297.

[26] H. Santiko, Dewi Sri di Jawa. Jakarta: Pusat Penelitian Purbakala dan Peninggalan Nasional, 1980.

[27] H. Santiko, Dewi Sri Unsur Pemujaan Kesuburan pada Mitos Padi dalam Majalah Ilmu-Ilmu Sastra Indonesia (MISI), vol. VII, no. 3. Yogyakarta: Fakultas Sastra, 1977.

[28] E. . James, Mother Goddes. London:Thames Hudson, 1961.

[29] T. K. S. Dewi, Dewi Sri Sebagai Mitos Kesuburan dan Realitasnya dalam Masyarakat Jawa. Dalam Teks, Naskah, Dan Kelisanan Nusantara. Jakarta: Yayasan Pernaskahan Nusantara, 2011.

[30] E. Yetti, "Laporan Perekaman Tradisi Lisan Kupang NTT,” 2011.

[31] S. Sunarti, Dengan Bailau Memanggil Harimau: Tradisi Lisan Bailau dari Bayang Pesisir Selatan Sumatera Barat. Jakarta: LIPI Press, 2020. 